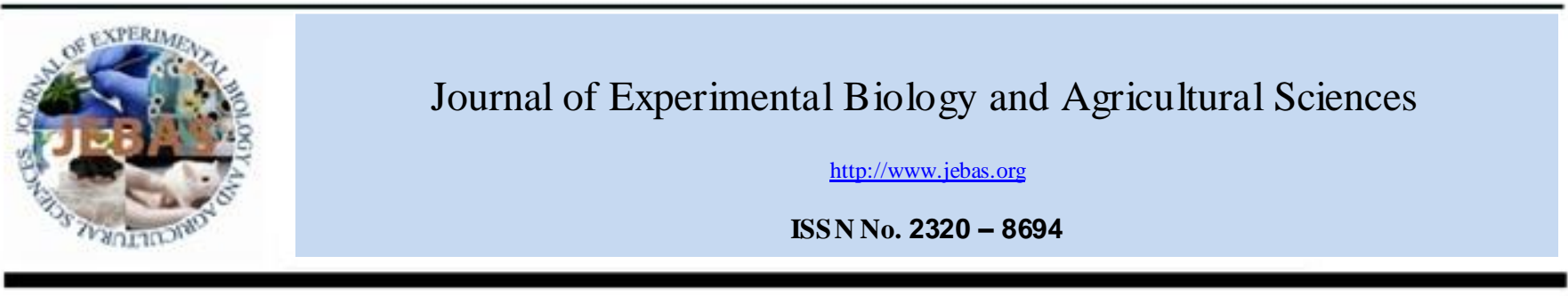

\title{
EFFECT OF VERMICOMPOST AND CHEMICAL NITROGEN FERTILIZER APPLICATION ON THE VARIOUS FUNCTIONING OF MAIZE SEEDS
}

\author{
Esmaeil Namazi ${ }^{1, *}$, Shahram Lack ${ }^{1}$ and Ebrahim Fatahi Nejad ${ }^{2}$ \\ ${ }^{1}$ Departments of Agronomym Ahvaz Branch, Islamic Azad University, Ahvaz,Iran \\ ${ }^{2}$ Departments of soil sciences, Behbahan Branch, Islamic Azad University, Behbahan, Iran \\ Received - February 11, 2015; Revision-February 25, 2015; Accepted - June 07, 2015 \\ Available Online - June 19, 2015 \\ DOI: http://dx.doi.org/10.18006/2015.3(3).261.268

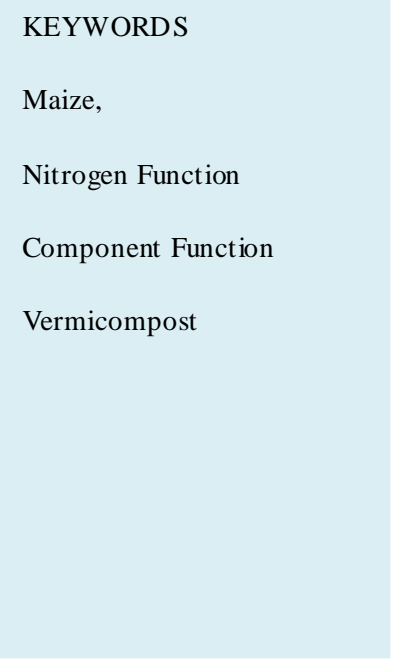

\begin{abstract}
ABSTRAC T
Present study was conducted to analyze the effect of Vermicompost and chemical Nitrogen fertilizer on the function and component of maize seed traits. A factorial test with complete randomize block designs was conducted at the city of Behbahan in the year 2012 with 4 repetitions. Analyzed treatments contains three level of chemical Nitrogen fertilizer viz 50, 75 and 100 percent of soil test area and application of vermicompost is also conducted at 3 levels of check (0), 5 and 10 tons in hectare. Results of the study showed a significant correlation between the quantitative traits of maize seed and various levels of chemical Nitrogen fertilizer and vermicompost. Highest functioning of maize seed was obtained from the treatment containing 100 percent Nitrogen and 10 tons/hectare of vermicompost while the lowest amount was obtained from the treatment containing 50 percent Nitrogen without vermicompost application. Furthermore, application of vermicompost and chemical Nitrogen fertilizer affects the biological function and increase in the yield of seed in rows and weight of each 1000 seeds, also has positive and meaningful effect on the index of maize seed's harvesting. The results of the study revealed that the application of Nitrogen fertilizer at the levels of 50 and 75 percents of area soil test and vermicompost at the level of 5 tons in a hectare in this area are appropriate to obtain the maximum yield and proper functioning.
\end{abstract}

* Corresponding author

E-mail: esmaeilnamazi@y ahoo.com (Esmaeil Namazi)

Peer review under responsibility of Journal of Experimental Biology and Agricultural Sciences.

Production and Hosting by Horizon Publisher (www.myvision.webs.com/horizon.html).

All rights reserved.
All the article published by Journal of Experimental Biology and Agricultural Sciences is licensed under a Creative Commons Attribution-NonCommercial 4.0 International License Based on a work at www.jebas.org.

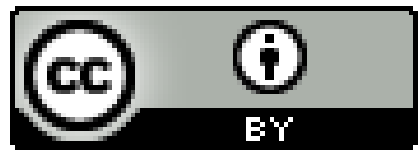




\section{Introduction}

Maize is one of the most important crops of the central and So uthern America and its history related to cultivation in Asia, Europe, Africa and Oceania is not much older but the conditions of these area are suitable for its cultivation (Khaje poor, 2007; Majnoon Hosseini, 2006). Recently, areas for maize cultivation and its consumption have been increased rapidly in all over the world and this may be because of its importance for producing different products.

At present the cultivation area for maize has been reached up to 140 million hectare and its yield is about 468 million tons which has third place in crop production after wheat and rice (Majnoon Hosseini, 2006). Maize needs different kinds of nourishment during its growth which can be obtained from the chemical fertilizers. Nitrogen is the one of the most important element which used for the maize cultivation and its deficiency can be limiting the nutritional elements of this crop (Khalid Berin \& Islam zadeh 2001). Considering the environmental pollution related to excess use of nitrogen fertilizer, needs of an alternative approach based on biological origin, safe for use and less expensive generated for the management of nitrogen. Replacement of nitrogen fertilizer in the soil through application of vermicomost can caused reduction in the environmental pollution developed by washing nitrate from the soil. According to Amo Aghaee et al. (2003), this type of organic fertilizers are not only safe for environment but if it applied in higher does, unused nitrogen remained in soil in the form of organic nitrogen and it will eventually return to the plant at the times of its need by process of becoming mineral.

Furthermore, Nanjappa et al. (2001) and Jayanthi et al. (2002) suggested that application of vermicompost and manure together showed a positive and meaningful improvement in the maize and oat seed's functioning. Findings of these researches clearly indicated that the use of vermicompost not only causes better plant's growth but also effects the crop functioning. Use of vermicompost in the sustainable agriculture caused significant increases in the population of beneficial microorganism such as mycorrhizal fungi and phosphate dissolving bacteria and fungi in the soil. Production of nutritious elements such as nitrogen, transferable phosphor, magnesium, dissolved potassium required for the plants and causes improvement in the growth and function of the agricultural plants (Martinez et al., 2000; Kumar \& Singh, 2001; Srivastava et al., 2002). Information's regarding the effect of fertilizers on the functioning of maize crop are in scarcity therefore present study has been conducted to find out the effect of chemical nitrogen fertilizer and vermicompost on the function and component of maize seed traits.

\section{Materials and Methods}

Present study was conducted in the cropping season of 2012 at agricultural field located in the city of Behbahan located in Khozistan province of Iran. The test was conducted in complete random fact orial block design with 4 time repetitions. First factor consisted of nitrogen chemical fertilizer at 3 different levels i.e. 50, 75 and 100 percent nitrogen according to the area soil test and the second factor consisted of vermicompost in 3 different levels i.e. check (0) 5 and 10 tons in a hectare. The nitrogen fertilizer has been added to the soil at 3 different stages. Chemical and physical properties of the studied area soil are mentioned in the table 1.

To calculate the seeds' functioning after emission of two border lines of each plot, sample has been collected from the center of the plot and after separating the seeds, the seeds have been collected from each plot separately and weighed precisely with the weighing scale and therefore the function of the seeds have been calculated from each plot in $\mathrm{kg} /$ hectare. To determine the seed's traits of each row, randomly five ear were selected from the plant and various trait were calculated. Weights of 1000 seeds have been taken by the use of precise electronic weighing scale at the precision of 0/0001 gram. Harvesting index has been calculated with the following relation:

$$
\text { Harvesting index }=\frac{\text { economical functioning }}{\text { biological functioning }} 100
$$

In the mentioned relation the economical product consisted of seed's function and biological function which consisting of total dried weight of all the aerial organs (seed and straw).

Table 1.Chemical and physical properties of the study area soil.

\begin{tabular}{|cccccccccc|}
\hline $\begin{array}{c}\text { Absorbable } \\
\text { potassium(mg/kg) }\end{array}$ & $\begin{array}{c}\text { Absorbable } \\
\text { phosphor }(\mathrm{mg} / \mathrm{kg})\end{array}$ & $\begin{array}{c}\text { Total } \\
\text { nitrogen }(\mathrm{kg})\end{array}$ & $\begin{array}{c}\text { Organic } \\
\text { Carbon }(\%)\end{array}$ & Ph & EC(ds/m) & $\begin{array}{c}\text { Soil } \\
\text { grade }\end{array}$ & $\begin{array}{c}\text { Sand } \\
(\%)\end{array}$ & $\begin{array}{c}\text { Silit } \\
(\%)\end{array}$ & $\begin{array}{c}\text { Clay } \\
(\%)\end{array}$ \\
\hline 205 & 8.5 & 0.034 & 0.71 & 7.4 & 2.6 & $\begin{array}{c}\text { Silt } \\
\text { loam }\end{array}$ & 12 & 58 & 30 \\
\end{tabular}




\section{Results and Discussion}

\subsection{Biological functioning of maize}

Considering the results of variance analysis, it was reported that effect of chemical nitrogen fertilizer consumption and its mutual effect with vermicompost (at a possible level of 5\%) has a significant effect on the biological function of maize, while the individual application of vermicompost had nonsignificant effect in the various trait of maize (table 2). Application of 75 and 100 percent of nitrogen fertilizer shows significant difference in the biological function as compared to 50 percent but there are no significant differences between these two.

Increased dose of vermicompost does not show any significant effect on the quality of maize seed. Among the various tasted vermicompost doses only 5tone/ha shows meaningf ul effect on the quality of the maize but this is also at par the rest two level of vermicompost (Table 3). Adding vermicompost to the soil not only increased the nutritious elements needed for the plant but also improved the physical conditions and living processes of the soil.

Furthermore, adding vermicompost also favor the condition for root growth and increase the growth of the aerial organs and production of dry materials and finally improvement in the biological function of the plant. Cavendera et al. (2003) obtained the similar results when they inoculated vermicompost to sorghum plant, they reported that vermicompost cause increase in the plant's component function and biological function of sorghum plant by stimulating the soil's useful micro organism activities and continuous supply of mineral elements especially nitrogen for the plant.

Table 2 Results of variance analysis, seed's component function and harvesting index of maize seed.

\begin{tabular}{|lccccccc|}
\hline Changes Resources & $\begin{array}{c}\text { degree of } \\
\text { freedom }\end{array}$ & $\begin{array}{c}\text { Biological } \\
\text { yield }\end{array}$ & Seed yield & $\begin{array}{c}\text { Harvesting } \\
\text { index }\end{array}$ & $\begin{array}{c}\text { no. of seed } \\
\text { row in each } \\
\text { maize }\end{array}$ & $\begin{array}{c}\text { No. of seeds } \\
\text { in each row }\end{array}$ & $\begin{array}{c}\text { Weight of } \\
1000 \text { seeds }\end{array}$ \\
\hline Repeat & 3 & $22311631.4^{\mathrm{ns}}$ & $407109.9^{\mathrm{ns}}$ & $39.92^{\mathrm{ns}}$ & $2.185^{\mathrm{ns}}$ & $20.917^{\mathrm{ns}}$ & $4254.99^{\mathrm{ns}}$ \\
\hline Nitrogen & 2 & $98560716.4^{*}$ & $784244.5^{\mathrm{ns}}$ & $338.83^{* *}$ & $0.222^{\mathrm{ns}}$ & $10.194^{\mathrm{ns}}$ & $3393.53^{\mathrm{ns}}$ \\
\hline Vermicompost & 2 & $2857129.4^{\mathrm{ns}}$ & $3054344.7^{* *}$ & $0.699^{\mathrm{ns}}$ & $2.889^{\mathrm{ns}}$ & $17.028^{\mathrm{ns}}$ & $4462.55^{\mathrm{ns}}$ \\
\hline Nitrogen*vermicompost & 4 & $59735344.5^{*}$ & $6379733.1^{* *}$ & $184.29 * *$ & $5.111^{\mathrm{ns}}$ & $14.361^{\mathrm{ns}}$ & $3218.187^{\mathrm{ns}}$ \\
\hline Error & 24 & 19369318.3 & 291618.1 & 34.384 & 1.435 & 60.208 & 4131.870 \\
\hline Changes coefficients $\%)$ & - & 18.48 & 4.89 & 12.69 & 9.02 & 20.05 & 20.89 \\
\hline
\end{tabular}

$*, * *, \mathrm{~ns}$ : are meaningful respectably at the possible levels of $5 \%$ and $1 \%$ and shows non-meaningful differences.

Table 3 Table of average comparison of simple traits study.

\begin{tabular}{|c|c|c|c|c|c|c|}
\hline Treatments & $\begin{array}{c}\text { Biological yield } \\
\text { (kg/ha) }\end{array}$ & $\begin{array}{l}\text { Seed yield } \\
\text { kgha }\end{array}$ & $\begin{array}{c}\text { Harvesting } \\
\text { index } \%\end{array}$ & $\begin{array}{c}\text { No. of rows } \\
\text { seeds in a } \\
\text { maize }\end{array}$ & $\begin{array}{l}\text { No. of seeds in } \\
\text { arrow }\end{array}$ & $\begin{array}{l}1000 \text { seeds } \\
\text { weight }\end{array}$ \\
\hline \multicolumn{7}{|c|}{ Nitrogen ( kg / hectare) } \\
\hline $\mathbf{5 0 \%}$ & $21134.83^{\mathrm{c}}$ & $10763.42^{\mathrm{a}}$ & $52.11^{\mathrm{a}}$ & $13.33^{\mathrm{a}}$ & $37.83^{\mathrm{b}}$ & $288.46^{\mathrm{b}}$ \\
\hline $75 \%$ & $26836.08^{\mathrm{a}}$ & $11076.69^{\mathrm{a}}$ & $41.81^{\mathrm{c}}$ & $13.33^{\mathrm{a}}$ & $38.58^{\mathrm{a}}$ & $315.22^{\mathrm{a}}$ \\
\hline $100 \%$ & $23473.60^{b}$ & $11270.00^{\mathrm{a}}$ & $44.71^{\mathrm{b}}$ & $13.16^{\mathrm{a}}$ & $39.66^{\mathrm{a}}$ & $319.49^{\mathrm{a}}$ \\
\hline \multicolumn{7}{|c|}{ Vermicompost (ton/hectare) } \\
\hline $\mathbf{0}$ & $23282.52^{\mathrm{b}}$ & $11474.83^{\mathrm{a}}$ & $45.94^{\mathrm{a}}$ & $13.00^{\mathrm{a}}$ & $40.00^{\mathrm{a}}$ & $322.78^{\mathrm{a}}$ \\
\hline 5 & $24240.91^{\mathrm{a}}$ & $11150.15^{\mathrm{a}}$ & $46.40^{\mathrm{a}}$ & $13.66^{\mathrm{a}}$ & $38.14^{\mathrm{b}}$ & $314.40^{\mathrm{a}}$ \\
\hline 10 & $23921.08^{\mathrm{a}}$ & $10485.13^{\mathrm{b}}$ & $46.29^{\mathrm{a}}$ & $13.16^{\mathrm{a}}$ & $37.66^{\mathrm{b}}$ & $285.99^{\mathrm{b}}$ \\
\hline
\end{tabular}

Averages having common letters in each column show significant differences at the level of $5 \%$ on the basis of Donken test 


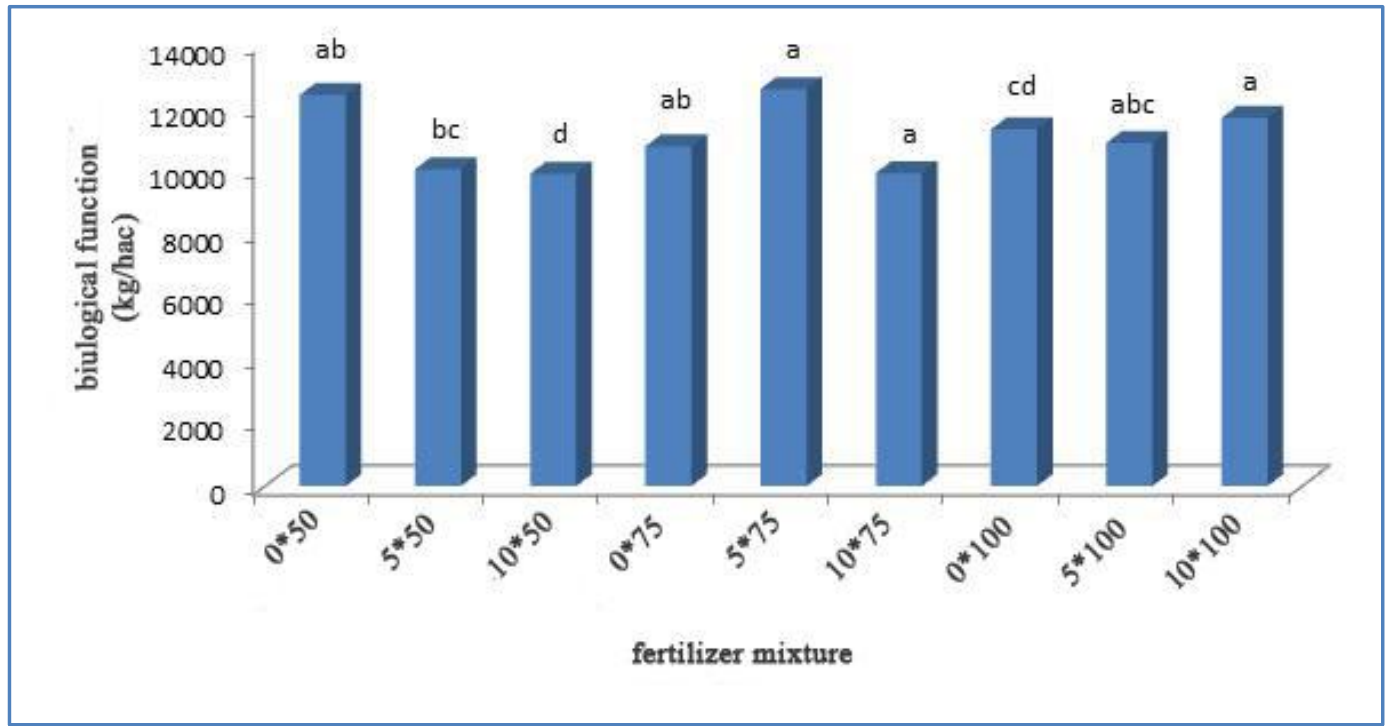

Figure 1 Effect of combined application of vermicompost and nitrogen fertilizer on the biological yield of maize plants

3.2 Effect of vermicompost and nitrogen fertilizer on Seed's yield

Results of variance analysis showed that vermicompost and combination of chemical nitrogen fertilizer and vermicompost at the possible level of $1 \%$ on the amount of seed's function was meaningful and effect of nitrogen chemical fertilizer on this contribution is meaningless (Table 2). Results of treatment interaction showed that the highest maize yield function $(12566 \mathrm{kgs} / \mathrm{hectare})$ was reported at the 5 tons vermicompost together with the use of $75 \%$ nitrogen while the lowest seed yield $(9890 \mathrm{kgs} / \mathrm{hectare})$ was reported from the combination of 10 tons vermicompost and 50\% nitrogen.

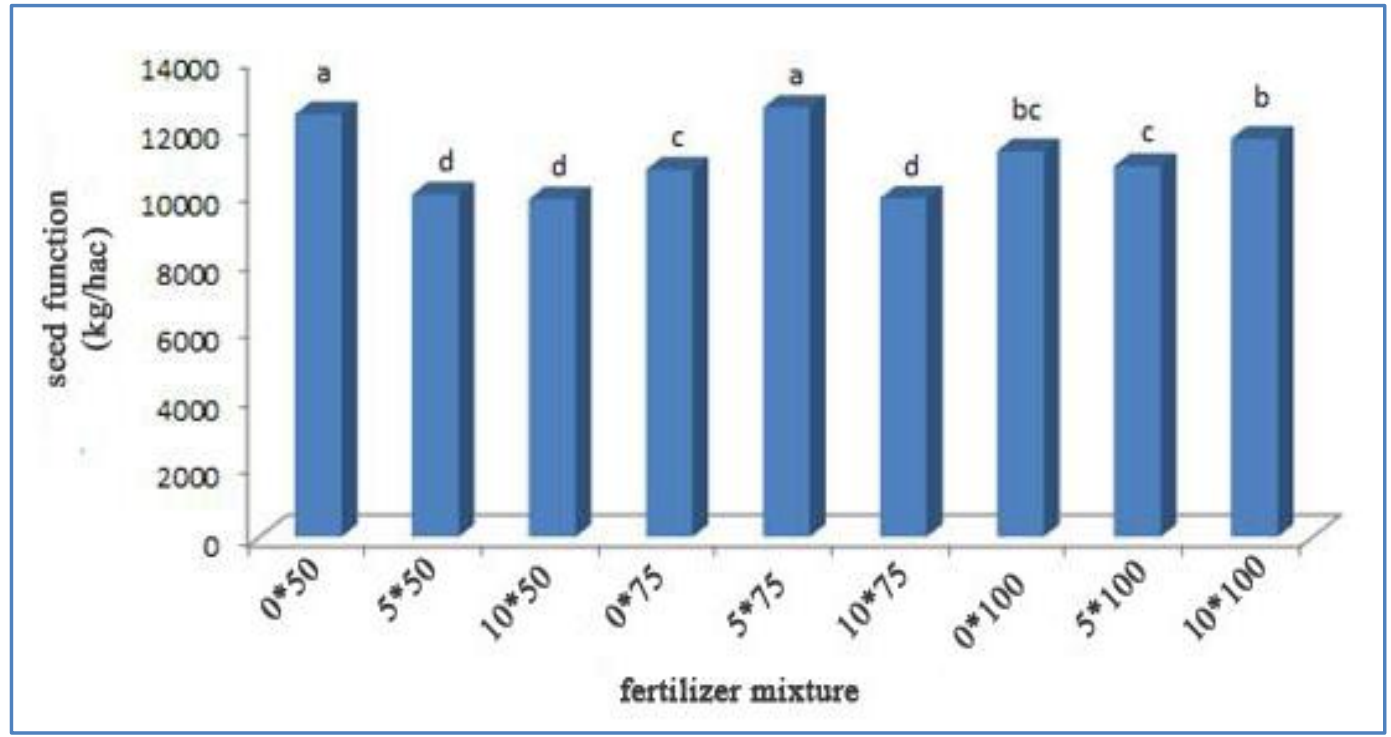

Figure 2 Effect of combined application of vermicompost and nitrogen fertilizer on the seed yield 
It was also observed that application of 10 tons of vermicompost without the use of nitrogen and the application of 10 tons vermicompost and 100 percent nitrogen in the area does not show any significant differences, but this can stop the use of $50 \%$ extra nitrogen. Generally application of vermicompost could add suitable nutritious element to the plant at acceptable amount but cause the suitable condition for the growth and increase functioning.

\subsection{Harvesting index}

Harvesting index in relation to the seed functioning depends on the dry weight or biomass, which is due to the effect of different elements such as type and genotype of the plant, environmental conditions, nitrogen fertilizer, density and date of cultivation. Results of the study revealed the effect of nitrogen fertilizer and the mutual effect of this fertilizer with vermicompost at the possible level of $1 \%$ was significant while the individual application of vermicompost shows nonsignificant effect (Table 2).

Paperi Moghadam Fard \& Bohrani (2005) reported that the harvesting index of sesame without being influenced by the nitrogen. They have reported that the harvesting index of sesame has been influenced by the genetic traits and nitrogen application which has non-significant influence on this trait.

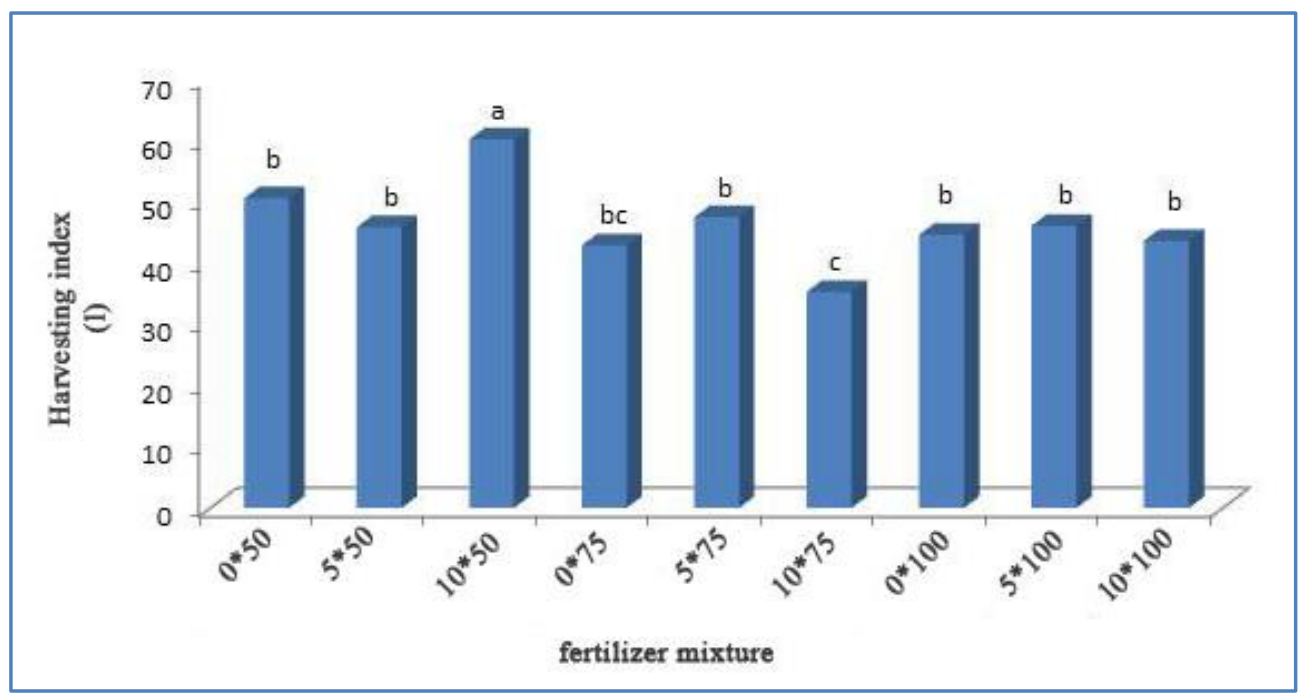

Figure 3 Effect of vermicompost and nitrogen fertilizer on the harvesting index

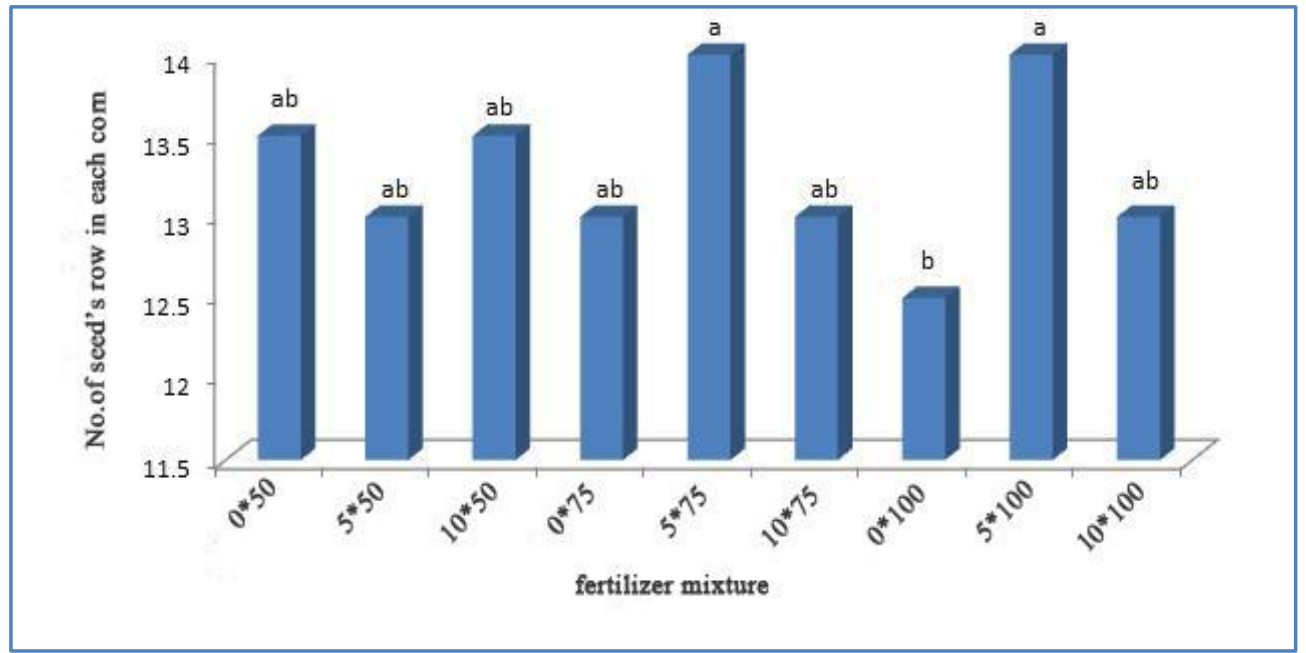

Figure 4 Effect of combined application of vermicompost and nitrogen fertilizer on the number of seed's rows in each corn 


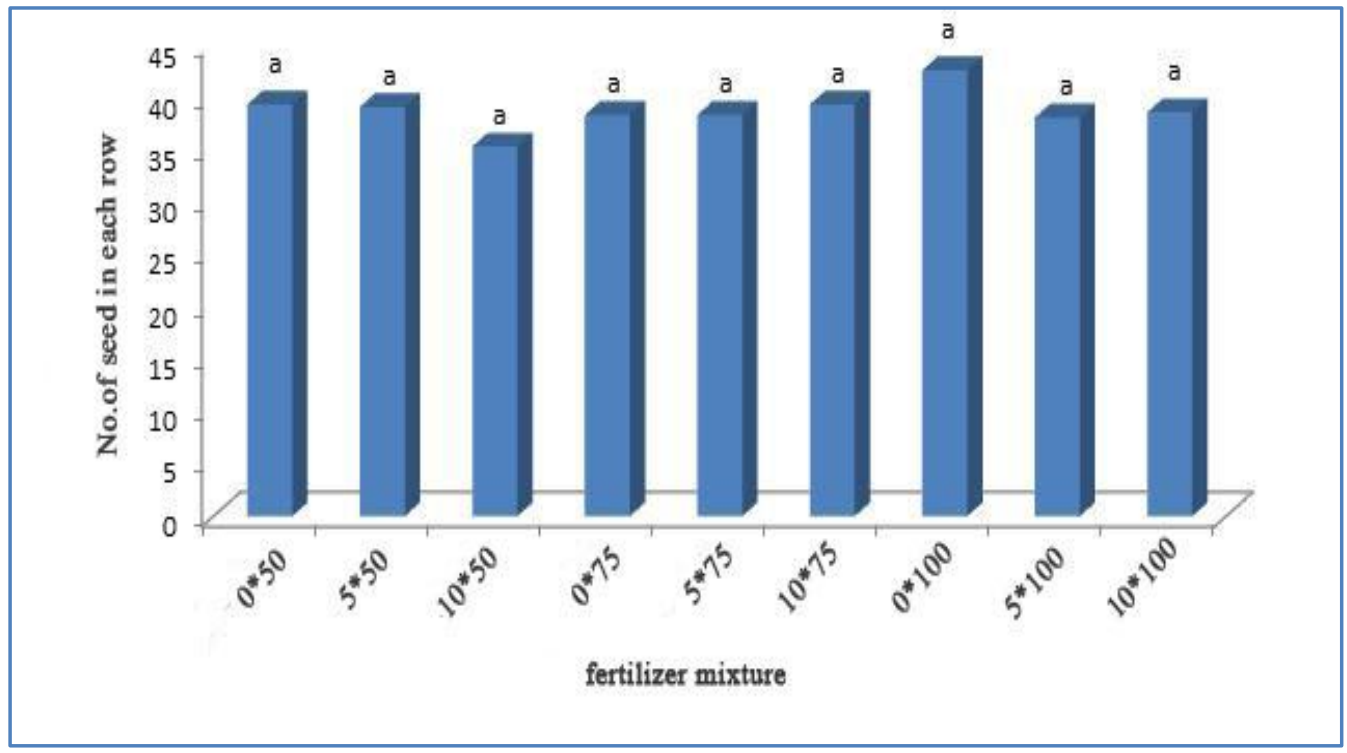

Figure 5 Mutual effect of application of vermicompost and nitrogen fertilizer on the number of seeds in each row

\subsection{Number of seed rows in one ear of maize}

Results of variance analysis showed that the effect of nitrogen fertilizer and vermicompost and their mutual effect on the number of seed rows in maize is meaningless (Table 2). Results of average comparison show that the highest (13.33) and the lowest (13.16) number of maize seed row was reported from the treatment containing 100 and $50 \%$ of the nitrogen fertilizer doses respectively. Furthermore, in case of vermicompost use, the highest (13.66) and lowest (13.00) number of maize seed rows was reported from the 5ton/ha and without vermicompost treatment respectively (Table 3 ). According to the results obtained from interaction between nitrogen fertilizers and vermicompost, the highest number of maize seed's rows was reported from the treatments containing the combination of 100 percent of nitrogen fertilizer soil test and 5tons/hectare vermicompost. This treatments was immediately followed by the combination of 75 percent of nitrogen fertilizer soil test and 5tons/ha vermicompost. Among the various tested treatments the lowest number of maize seed's rows was reported from the 100 percent nitrogen fertilizers without vermicompost. Increases in the amount of nitrogen caused decrease in the emission of flowers and increase in the plant greenery level cause increase in the production of photosynthesis materials, duration of flowering and flowers fertility and therefore increase in the number of seed's rows in the maize and since use of nitrogen fertilizer causes increase in the biochemical activity of photosynthesis, therefore the number of leaves increases and the duration of growth and collection of dry material of aerobic organs have been effected and it seems that the effect of increase on this condition is logical.

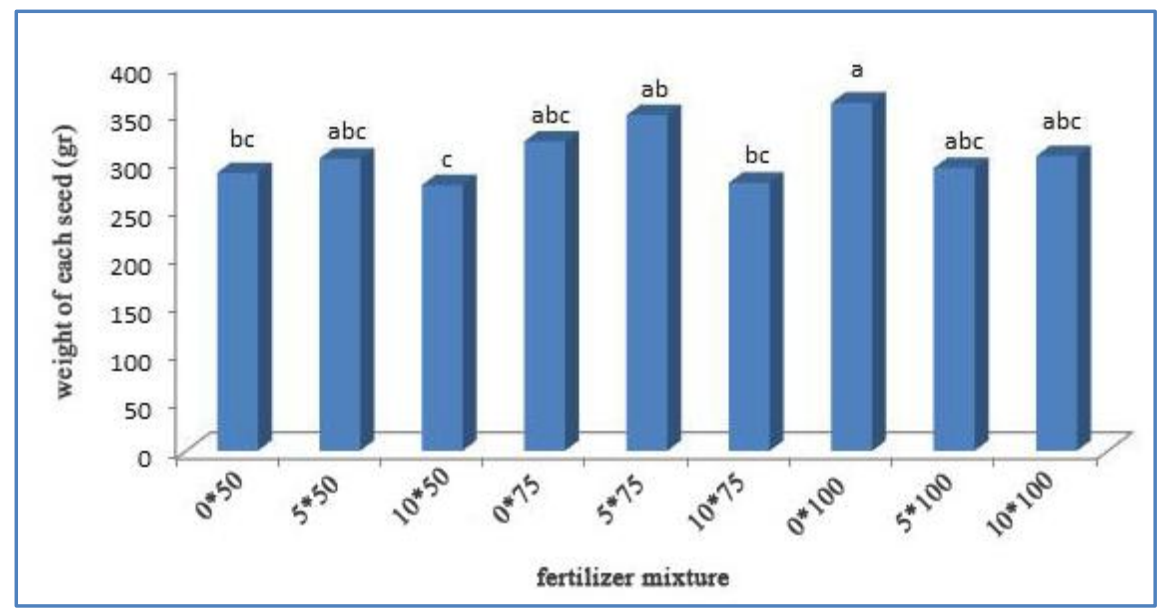

Figure 6 Combined effect of the application of vermicompost and nitrogen fertilizer on the weight of 1000 seeds 
3.5 Number of seeds in each row

Individual as well combined application of nitrogen fertilizer and vermicompost didn't show any significant effect on the number of seed per row at analysis of variance study (Table2). Results obtained from comparison of averages show that the highest (39.66) and lowest (37.83) number of seeds in a row was reported from the treatment containing nitrogen fertilizer at the amount of $100 \%$ and $50 \%$ belong to the soil test respectively. Furthermore, in case of vermicompost, the highest and lowest number of seeds in a row was reported from the treatments without the use of vermicompost fertilizer and the use of vermicompost at the amount of 5 tons per hectare (table 3). Analysis of results related to the interaction of nitrogen fertilizer treatments and vermicompost showed that the highest number of seeds in a row was reported from the treatments containing nitrogen 1 fertilizer at the amount of $100 \%$ soil test without the use of vermicompost respectably while the lowest number of seeds in a maize belong to the treatment with the use of nitrogen fertilizer at the amount of $50 \%$ soil test and use of vermicompost at the amount of 10 tons in hectare. These results can be justified the fact that more nitrogen can cause production of biomass, and the amount of photosynthesis in the plant will increase and plant could not produce and maintain more seeds. Furthermore, these fertilizers help in spreading of roots which increased the rate of absorption. This caused increase in the leaves level which again cause more photosynthesis materials and therefore the materials which produced due to photosynthesis process and if at the time of stimulation, seed's PRIMORDEYA will take place and causes improvement in the seed's function and the number of seeds; therefore this condition causes coordination in the seed's function and therefore this result is logical in the increase of the number of seeds in a row.

3.6 Weight of each 1000 seeds:

According to the results of variance analysis, the treatments containing nitrogen fertilizer, vermicompost and the combination of both did not show any significant difference (Table 2). Results of average comparison showed that with increasing the use of nitrogen fertilizer the weight of each 1000 seeds were also increased even though statistical analysis was not showing significant differences between these condition and level of nitrogen application. Furthermore the use of vermicompost cause reduction in the weight of 1000 seeds (Table 3).

Jashankar \& Wahab (2004) reported positive effects of vermicompost on the seed weight in this manner finding of the present study are contradictory to the findings of these researchers. The possible reason for positive effect of vermicompost on the seeds weight was the presence of the useful aerobic microorganisms such as Azetobacteria. Jayshanker \& Vahab (2004) also mention that the pit material such as pores, capacity for over all airing, canalization and capacity for maintaining water at a high level for absorption of nutritious are among the advantages of vermicompost.
Nanjappa et al. (2001) reported a positive effect of vermicompost on each 1000 maize seeds.

\section{Conclusion}

In general application of vermicompost has positive effect on the seed's functioning, biological function, number of the seed in each row and weight of 1000 seeds. Considering the results obtained it can be suggested that vermicompost can be used as the supplement of chemical fertilizers and have positive effect on the environment as well reduces the pollution in the area.

\section{Conflict of interest}

Authors would hereby like to declare that there is no conflict of interests that could possibly arise.

\section{References}

Amo Aghaee, Raihane, Mostajeran A, Amteyazi G (2003) Effect of Azosperilium bacteria on some of the growth indices and 3 types of wheat functioning. Agricultural and Natural Resources 82: 127-139

Cavender ND, Atiyeh RM, Knee M (2003) Vermicompost stimulates mycorrhizal colonization of roots of Sorghum bicolor at the expense of plant growth. Pedobiologia 47: 8589.

Jashankar S, Wahab K (2004) Effect of integrated nutrient management on the growth, yield components and yield of Sesame. Sesame and Safflower Newsletter 20:602-608 available http://ecoport.org/ep?SearchT ype=earticleVie w\&earticleId=73 2\&page $=-2$ access on 20 April, 2015.

Jayanthi C, Malarvizhi P, Fazullah Khan AK, Chinnusamy C (2002) Integrated nutrient management in forage oat (Avena sativa). Indian Journal of Agronomy 47:130-133.

Khaje poor MR (2007) Industrial Crops. Jihad Press University of Technology Pp. 580.

Khalid Berin B, Islam zadeh T (2001) Mineral Feeding of organic plants ( authore: tourist KharShotor). Shiraz University publication Pp 945.

Kumar V, Singh KP (2001) Enriching vermicompost by nitrogen fixing and phosphate solubilizing bacteria. Bioresource Technology 76: 173-175. doi:10.1016/S09608524(00)00061-4.

Majnoon Hosseini N (2006) Cerals agronomy (wheat, barley, rice, zea mays). Naghsh mehr publication Pp 116. [In Persian]

Manjarrez MJ, Ferrera-Cerrato R, Gonzalez-Chavez MC (2000) Effect of vermicompost and mycorrhizal fungi on 


\section{8 \\ growth and photosynthetic rate of chilli. Indian} Phytopathology 17: 195-197.

Srivastava AK, Singh S, Marathe RA (2002) Organic Citrus: Soil Fertility and Plant Nutrition. Journal of Sustainable Agriculture 19: 5-29. doi: 10.1300/J064v19n03_03.
Nanjappa HV, Ramachandrappa BK, Mallikarjuna BO (2001) Effect of integrated nutrient management on yield and nutrient balance in maize (Zea mays L.). Indian Journal of Agronomy 46: 698-701.

Paperi Moghadam Fard A, Bohrani M J (2005) Effect of N application and plant density on some agronomical traits of sesame. Iranian Journal of Agricultural Sciences 36: 129-134. 